\title{
Gambling as an Economic Development Strategy: The Neglected Issue of Job Satisfaction and Nonpecuniary Income
}

\author{
Benjamin F. Blair, R. Keith Schwer, and C. Jeffrey Waddoups*
}

\begin{abstract}
Economic impact analyses of proposed new gaming venues have focused on such pecuniary factors as the number of jobs and the increase in income likely to accompany gaming development projects, while ignoring nonpecuniary components of compensation. If nonpecuniary compensation is not accounted for, economic impact assessments of development options will not reflect the true impact of alternative development options. Results of this study suggest that employees in gaming industry occupations are less satisfied with their jobs than those in other industries. Community decision makers who are considering the option of gaming to develop their local and regional economies should be aware not only of the quantity, but of the quality of employment that will be created should gaming be introduced into their areas.
\end{abstract}

\section{INTRODUCTION}

Facing economic and fiscal stress, many state and local communities have considered legalized gambling as an economic development strategy (Alm, Mckee, and Skidmore 1993). Impact analyses of proposed gaming projects, often completed to persuade the public, have focused mainly on economic impacts increased jobs and income - associated with proposed gaming establishments. Social costs accompanying gaming, usually defined as the increased incidence of compulsive gambling and increases in crime, incarceration, child abuse and neglect, alcoholism, and lost work time, are also sometimes considered, although usually with less specificity than income and employment effects.

Economic and social impact studies of gaming have been criticized for being unbalanced, misusing data, and incorrectly applying impact models, which result in a misstatement of potential benefits and costs (Goodman 1994). These criticisms notwithstanding, benefits may also be misstated if an inadequate income measure is used. Though the "full wage" considered by workers in labor market decisions consists of both pecuniary and nonpecuniary returns to work, gambling impact studies have generally focused on pecuniary returns only. By focusing on pecuniary returns to work, the analyst implicitly assumes that nonpecuniary factors are similar across development options. If jobs created from gaming development offer substantially lower nonpecuniary returns to employment than alternatives, then economic and social impact studies that do not account for these disparities will overstate potential benefits of a proposed development project. 
The present study compares nonpecuniary returns to employment in gaming industry jobs with jobs outside the gaming industry by examining differences in job satisfaction of workers in the two groups. To be sure, legalization of gaming may increase a region's employment opportunities. Though the pecuniary and nonpecuniary returns increase for previously unemployed workers now able to find employment, the net effect may not be readily apparent, especially for regions experiencing the transitory effects associated with recent gambling legalization. Our results, based on findings for a more mature gaming environment, suggest that nonpecuniary returns associated with jobs in the gaming industry are systematically lower than returns connected with jobs in other industries. It is likely, therefore, that impact analyses overestimate the benefits of gaming relative to other nongaming development options if regions forego alternative economic development options which create employment characterized by greater job satisfaction.

A comparison of job satisfaction between gaming and similar nongaming occupations may also be of interest to management in the gaming industry. Low job satisfaction has been found to increase job turnover, making it more difficult and expensive to attract a highly qualified and productive workforce (Akerlof, Rose, and Yellen 1988, Freeman 1978). Indeed, the recent identification of Mirage Resorts as one of the nation's most admired companies, ranking second overall and third in attracting, developing, and keeping motivated employees, points to the recognition by gambling firms of the importance of employees' work environment (Robinson 1997). Thus, gaming operators seeking better economic performance may find measures and determinants of relative job satisfaction of interest.

The remainder of the study proceeds as follows: first, we review the literature on job satisfaction and its connection with nonpecuniary returns to employment. Second, we discuss the data and the econometric model. Third, we present and discuss estimation results. Finally, conclusions are drawn, implications for policy are outlined, and suggestions for further research are considered.

\section{NONPECUNIARY INCOME AND JOB SATISFACTION}

Economists have long recognized that returns to work accrue in the form of pecuniary and nonpecuniary rewards. In recognition of the nonpecuniary component of compensation, economists have conceptualized the "full wage," which consists of both pecuniary and nonpecuniary elements (Borjas 1978, Thurow 1978, Bartel 1981, Akerlof, Rose, and Yellen 1988). Pecuniary components of compensation include pay, benefits, job security and the like. Nonpecuniary elements consist of other factors that affect workers' well-being on the job, such as the nature of interactions with co-workers and customers, risk of death or injury, control of the work process, and environmental conditions, among other characteristics.

The intangible nature of nonpecuniary compensation and the lack of good data largely explain its lack of consideration in economic impact studies. However, if a substantial portion of income consists of nonpecuniary rewards and it is left out of the analysis, then income and welfare impacts of development options will not reflect the true impact of a proposed development project. 
Evidence from the literature supports the notion that nonpecuniary characteristics of a job are a significant component of total compensation. Akerlof, Rose, and Yellen (1988) estimate that the average value of nonpecuniary rewards of respondents in the National Longitudinal Survey of Mature Men $(1966,1971)$ is 54 percent of their reported salary. In a more recent study, McCue and Reed (1996) corroborate Akerlof, Rose and Yellen (1988) by demonstrating that younger workers also place a relatively large monetary value on nonpecuniary dimensions of their employment. The obvious implication is that regional well-being is also dependent on nonpecuniary characteristics of the jobs available in the area. Thus, a good regional development plan will attempt to account for nonpecuniary characteristics of jobs attracted to the area.

The intangible nature of nonpecuniary income renders it difficult to measure directly. However, in a recently published study on labor market discrimination against women in the legal profession, Laband and Lentz (1993) used job satisfaction as a proxy for nonpecuniary income. Though they found no evidence to suggest that pay, benefits, and promotion opportunities (all pecuniary rewards) differed for male and female attorneys, job satisfaction was substantially lower among female attorneys, which led them to conclude that discrimination along "intangible margins" is likely to exist. The approach taken in the present study is similar to that taken by Laband and Lentz (1993). That is, job satisfaction measures are used as proxies for nonpecuniary income.

\section{JOB SATISFACTION IN THE GAMING INDUSTRY}

Though economists have found job satisfaction to be a useful concept, the only published research on the topic that has specifically targeted the gaming industry was conducted by sociologists and social psychologists. Smith, Preston, and Humphries (1975) interviewed a sample of casino card dealers and found that workers experienced a high level of "powerlessness." Dealers also reported a high level of "meaninglessness" and "lack of intrinsic pride" in their work. Frey (1986) reached the same conclusion, finding a substantial majority of dealers in a survey indicated that their job was uninteresting, unpleasant, boring, and offered little sense of accomplishment. A large majority also indicated that they would "rather work somewhere else," "do not see themselves as a dealer in five years," and "do not like dealing as an occupation." These two studies suggest that the nonpecuniary component of compensations for dealers is quite low.

Although interesting and somewhat suggestive, the Smith, Preston, and Humphries (1975) and Frey (1986) studies narrowly focused on only one occupation (dealers) in the gaming industry and do not compare satisfaction levels of these workers with others in the industry or with workers outside the gaming industry. Recently, a small study comparing the job satisfaction level of poker dealers, arguably expected to rank among the lowest in job satisfaction in the gaming industry, with that of teachers took a step toward addressing this concern. Darcy and Lester (1995), using a common index of job satisfaction and a sample of 59 card dealers and 61 school teachers, reported mean values which suggested 
that school teachers were substantially more satisfied with their jobs than card dealers. Their study, similar to the earlier studies of gaming workers' job satisfaction, remains narrow in scope and not very informative for judging differences in nonpecuniary rewards across a wide spectrum of jobs in the gaming and nongaming industries. As a result, more reliable conclusions require a representative data set across a broad cross section of occupations in both gaming and nongaming sectors.

\section{STUDY METHODS}

\section{Data and Sample Characteristics}

The Las Vegas Metropolitan Area, long recognized as a regional economy with a significant gambling industry, offers a natural setting to generate a random sample containing sufficient responses from gaming employees. In a survey conducted in 1992, respondents completed a questionnaire containing questions about the nature of their occupation and how satisfied they were with a number of dimensions of their job. In addition, questions concerning personal and household characteristics that may have an impact on job satisfaction were included. The survey used a simple random sample design and mail format with one follow-up. We received 918 completed questionnaires from a mailing of 4,000 , yielding a 24.5 percent response rate. Three hundred and twenty-six cases provided complete information on all the variables after agreement with a filter question on employment status. Table 1 contains descriptive statistics describing the relevant characteristics of the sample used to conduct the analysis.

TABLE 1

Occupational and Personal Characteristics of the Sample ${ }^{1}$

\begin{tabular}{lr}
\hline $\begin{array}{l}\text { Characteristic } \\
\text { Industry }\end{array}$ & Proportion \\
Nongaming & 0.85 \\
Gaming & 0.15 \\
Type of Work & \\
Part-time & 0.05 \\
Shift work & 0.85 \\
Management & 0.22 \\
Professional/Technical & 0.41 \\
Services & 0.29 \\
Education & \\
No high school diploma & 0.05 \\
High school diploma & 0.18 \\
Some College & 0.40 \\
College Degree & 0.24 \\
Graduate Degree & 0.13 \\
& \\
Age & 0.41 \\
18-34 years & 0.50 \\
35-54 years & 0.09 \\
55+ years & 0.08 \\
Nonwhite & 0.59 \\
Female & 0.66
\end{tabular}


TABLE 1 (Continued)

Occupational and Personal Characteristics of the Sample ${ }^{1}$

\begin{tabular}{cc}
\hline $\begin{array}{l}\text { Characteristic } \\
\text { Income }\end{array}$ & Proportion \\
$\$ 0-\$ 14,999$ & 0.03 \\
$\$ 15,000-\$ 19,999$ & 0.06 \\
$\$ 20,000-\$ 24,999$ & 0.09 \\
$\$ 25,000-\$ 34,999$ & 0.15 \\
$\$ 35,000-\$ 49,999$ & 0.26 \\
$\$ 50,000-\$ 74,999$ & 0.23 \\
$\$ 75,000-\$ 99,999$ & 0.10 \\
$\$ 100,000+$ & 0.08 \\
\hline
\end{tabular}

Source: Las Vegas Perspective, 1992, Center for Business and Economic Research, University of Nevada Las Vegas. ${ }^{1}$ The total dataset contains 918 observations. Of these, 326 observations contained all of the information necessary to perform the regression analysis. This table is a description of these observations.

\section{MEASURES OF JOB SATISFACTION}

The questionnaire included 22 questions regarding various aspects of an individual's job satisfaction. Table 2 contains frequencies for these variables selected for occupations in gaming and nongaming industries. The questions read as follows: "Please check your satisfaction with respect to the following attributes of your work." The possible choices were "Very Satisfied," "Quite Satisfied," "Somewhat Satisfied," "Not at All Satisfied," and "Not Applicable." Using a chisquare test, we tested the null hypothesis that there is no difference between responses between gaming and nongaming populations with regard to 22 measures of job satisfaction.

TABLE 2

Cross-tabulations of Job Satisfaction Measures by Occupation Type ${ }^{1}$

\begin{tabular}{|c|c|c|c|c|c|c|}
\hline \multirow[b]{2}{*}{ Job Attribute } & \multirow[b]{2}{*}{ Industry } & \multicolumn{4}{|c|}{ Degree of Satisfaction } & \multirow[b]{2}{*}{ Chi Square $^{2}$} \\
\hline & & Very & Quite & Somewhat & Not at All & \\
\hline \multirow{2}{*}{ Achievement in Work } & Nongaming & 29 & 106 & 197 & 155 & 20.97 \\
\hline & Gaming & 6 & 33 & 17 & 17 & \\
\hline \multirow{2}{*}{ Advancement Opportunity } & Nongaming & 90 & 137 & 117 & 91 & 7.21 \\
\hline & Gaming & 19 & 27 & 12 & 8 & \\
\hline \multirow[t]{2}{*}{ Benefits } & Nongaming & 71 & 117 & 145 & 108 & 2.37 \\
\hline & Gaming & 13 & 24 & 18 & 18 & \\
\hline \multirow[t]{2}{*}{ Pride in Employer } & Nongaming & 43 & 111 & 157 & 127 & 19.36 \\
\hline & Gaming & 19 & 21 & 16 & 15 & \\
\hline \multirow[t]{2}{*}{ Contribution to Society } & Nongaming & 37 & 103 & 162 & 159 & 23.90 \\
\hline & Gaming & 11 & 27 & 25 & 6 & \\
\hline \multirow[t]{2}{*}{ Valued by Employer } & Nongaming & 47 & 102 & 159 & 135 & 15.48 \\
\hline & Gaming & 17 & 22 & 17 & 14 & \\
\hline \multirow[t]{2}{*}{ Feedback } & Nongaming & 84 & 128 & 151 & 70 & 11.54 \\
\hline & Gaming & 5 & 15 & 29 & 19 & \\
\hline \multirow[t]{2}{*}{ Independence in Work } & Nongaming & 22 & 896 & 144 & 217 & 31.50 \\
\hline & Gaming & 4 & 33 & 17 & 15 & \\
\hline \multirow[t]{2}{*}{ Influence in the Organization } & Nongaming & 75 & 117 & 130 & 104 & 30.50 \\
\hline & Gaming & 28 & 23 & 11 & 4 & \\
\hline \multirow[t]{2}{*}{ Influence in Work } & Nongaming & 51 & 104 & 148 & 131 & 24.66 \\
\hline & Gaming & 19 & 23 & 18 & 6 & \\
\hline \multirow[t]{2}{*}{ Job Interest } & Nongaming & 28 & 99 & 166 & 183 & 23.78 \\
\hline & Gaming & 10 & 28 & 21 & 12 & \\
\hline
\end{tabular}


TABLE 2 (Continued)

Cross-tabulations of Job Satisfaction Measures by Occupation Type ${ }^{1}$

\begin{tabular}{|c|c|c|c|c|c|c|}
\hline \multirow[b]{2}{*}{ Job Attribute } & \multirow[b]{2}{*}{ Industry } & \multicolumn{4}{|c|}{ Degree of Satisfaction } & \multirow[b]{2}{*}{ Chi Square } \\
\hline & & Very & Quite & Somewhat & Not at All & \\
\hline \multirow[t]{2}{*}{ Job Security } & Nongaming & 54 & 80 & 150 & 169 & 12.66 \\
\hline & Gaming & 18 & 13 & 20 & 16 & \\
\hline \multirow[t]{2}{*}{ Job Status } & Nongaming & 49 & 102 & 158 & 146 & 20.03 \\
\hline & Gaming & 6 & 32 & 19 & 11 & \\
\hline \multirow{2}{*}{ Meaningful Work } & Nongaming & 34 & 79 & 177 & 181 & 43.56 \\
\hline & Gaming & 15 & 25 & 23 & 57 & \\
\hline \multirow{4}{*}{$\begin{array}{l}\text { Personal Growth } \\
\text { Opportunities } \\
\text { Interactions with People }\end{array}$} & Nongaming & 71 & 105 & 151 & 127 & 24.23 \\
\hline & Gaming & 16 & 30 & 16 & 5 & \\
\hline & Nongaming & 14 & 79 & 187 & 198 & 5.28 \\
\hline & Gaming & 3 & 18 & 28 & 21 & \\
\hline \multirow{2}{*}{ Pay } & Nongaming & 86 & 146 & 142 & 93 & 2.78 \\
\hline & Gaming & 17 & 22 & 15 & 14 & \\
\hline \multirow{2}{*}{$\begin{array}{l}\text { Recognition for Doing } \\
\text { a Good Job }\end{array}$} & Nongaming & 72 & 144 & 151 & 104 & 14.72 \\
\hline & Gaming & 20 & 26 & 11 & 10 & \\
\hline \multirow[t]{2}{*}{ Responsibility } & Nongaming & 16 & 83 & 188 & 187 & 28.26 \\
\hline & Gaming & 9 & 24 & 22 & 14 & \\
\hline \multirow{2}{*}{ Fair Boss } & Nongaming & 51 & 106 & 143 & 142 & 5.70 \\
\hline & Gaming & 8 & 26 & 18 & 18 & \\
\hline \multirow{4}{*}{$\begin{array}{l}\text { Use of Ability and } \\
\text { Knowledge in Work } \\
\text { Work Conditions }\end{array}$} & Nongaming & 28 & 58 & 186 & 206 & 23.26 \\
\hline & Gaming & 6 & 22 & 24 & 16 & \\
\hline & Nongaming & 35 & 126 & 180 & 141 & 7.86 \\
\hline & Gaming & 9 & 26 & 21 & 14 & \\
\hline
\end{tabular}

Source: Las Vegas Perspective, 1992, Center for Business and Economic Research, University of Nevada Las Vegas.

${ }^{1}$ Cross-tabulations were performed for the entire 918 observations in the dataset. Total numbers for each attribute differ because some respondents evaluated only a portion of the job attributes.

"To reject the null hypothesis of no relationship between the variables "gaming occupation" and "job satisfaction" at the $10 \%$ level of significance requires a chi-square statistic of $6.25(7.81)$.

Results indicate a difference between gaming and nongaming occupations along many dimensions of job satisfaction. In general, gaming employees were less satisfied with a majority of the nonpecuniary aspects of their work. Of twenty-two job satisfaction measures, significant differences were found in 18 categories. The nonpecuniary characteristics include factors such as work's contribution to society, the independence in performing work, recognition received for work, influence exerted in work activities, personal growth derived from work, and meaningfulness of work, among others. We found no significant difference, however, between gaming and nongaming employees in satisfaction from the perceived fairness of workers' supervisors, interactions with people, and pecuniary components of work such as pay and benefits.

To be sure, any conclusions derived from simple cross-tabulations may be suspect, because variations in variables other than gaming occupation may also influence job satisfaction. For example, there may be a systematic difference in job satisfaction resulting from specific occupational categories, shift work, part-time work and such personal attributes as age, household income, education, gender, and race. To assess the impact of these variables on job satisfaction, we reduce the data on job satisfaction into a more manageable form. Using principle components factor analysis (Kline 1994), we found that the 22 job satisfaction questions measured three separate factors. Table 3 summarizes the components combined to 
produce the three factors. Nonpecuniary questions dominate the first two factors labeled "Working Conditions" and "Job Quality," respectively. Factor 3, labeled "Compensation," on the other hand, contains mostly pecuniary factors, that is, factors related to pay, benefits, and job security. The "Working Conditions" category contains two classes of nonpecuniary variables describing the work environment: first, satisfaction with the evaluation and supervision process, which includes feedback, recognition, fair treatment by supervisors and perceptions of being valued; and second, the ability to act on one's own initiative, which includes workers' assessments of influence in their organizations and independence in conducting their work. The "Job Quality" factor represents another group of nonpecuniary characteristics combining job characteristics, such as contribution of work to society, meaningfulness of work, and personal growth, among others. "Compensation" generally represents the workers' satisfaction with the pecuniary dimension of their jobs.

\section{TABLE 3}

Elements Used to Construct Aggregated Measures of Job Satisfaction

\begin{tabular}{l}
\hline Factor 1: "Working Conditions" \\
Feedback \\
Recognition for Doing a Good Job \\
Fair Boss \\
Valued by Employer \\
Influence in Work \\
Influence in the Organization \\
Independence in Work \\
Work Conditions \\
Factor 2: "Job Quality" \\
Meaningful Work \\
Job Interest \\
Achievement in Work \\
Use of Ability and Knowledge in Work \\
Responsibility \\
Personal Growth Opportunities \\
Contribution to Society \\
Interact with People \\
Job Status \\
Factor 3: "Compensation" \\
Penefits \\
Pay \\
Pride in Employer \\
Opportunity for Advancement \\
Job Security
\end{tabular}

Source: Las Vegas Perspective, 1992, Center for Business and Economic Research, University of Nevada Las Vegas.

We now describe the empirical model used to estimate the determinants of job satisfaction and the interrelationships between job satisfaction and income.

\section{A MODEL OF JOB SATISFACTION}

Following Rosen (1986), the labor market can be thought of as consisting of two submarkets. In the first, workers sell their labor services to employers in return for a wage payment; in the second, employers sell nonpecuniary job attributes, for example, risk of injury and other working conditions, to workers in 
return for wage premia, which are known as compensating differentials or equalizing differences. These two markets are simultaneous and the resulting "observed" or "full" wage is a combination of the wage payment and wage premia from each of the submarkets. Accepting a job implies that a worker chooses an "employment bundle" consisting of the observed wage (pecuniary) and nonpecuniary job attributes. Given two jobs that have identical wage payments, a worker will prefer the job with the more desirable nonpecuniary attributes. If a job offers less desirable levels of nonpecuniary attributes, the employer must offer a wage premium in order for that job to be chosen.

Our data only contain information on household income and not wages directly. Household income consists of the "wage payment" and "wage premia" for all householders, but we only observe job satisfaction measures for the respondent. The model implies that the respondent's job satisfaction level is representative of the household's and is dependent on their own money income and job attributes as well as the money income of the entire household. The use of household income rather than individual income is consistent with that notion that labor supply is a household decision (Killingsworth 1983).

The theory of compensating differences outlined above suggests that a lower level of satisfaction with nonpecuniary aspects of respondents' jobs will be compensated with higher levels of money income. Thus, we expect a negative correlation between satisfaction and household income. Because chi square tests, in general, revealed lower worker satisfaction in gaming occupations (see Table 2), we suggest that a relatively larger portion of the income derived from these occupations is a compensating differential accounting for the lower desirability of these occupations.

We use three measures of job satisfaction as measures of utility associated with nonpecuniary job attributes. These three measures are "working conditions," "job quality," and "compensation," labeled $\mathrm{S}_{1}, \mathrm{~S}_{2}$, and $\mathrm{S}_{3}$, respectively. The derivation of these measures was discussed above. Total utility, $U$, derived from a particular job is a function of household income and the three measures of satisfaction. Formally,

$$
\mathrm{U}=\mathrm{U}\left(\mathrm{I}, \mathrm{S}_{1}, \mathrm{~S}_{2}, \mathrm{~S}_{3}\right),
$$

where

$$
\mathrm{I}=\mathrm{I}\left(\mathrm{S}_{1}, \mathrm{~S}_{2}, \mathrm{~S}_{3} \mathrm{OC}, \mathrm{WC}\right)
$$

is the observed income which is a function of nonpecuniary job attributes as well as occupational characteristics (OC) and worker characteristics (WC). Occupational characteristics include whether or not the job is in the gaming industry and worker characteristics (WC) include attributes such as education, age, race, and gender. Each measure of job satisfaction is a function of occupational characteristics and worker characteristics as well as the household's income relative to similar households, so that

$$
\mathrm{S}_{\mathrm{i}}=\mathrm{S}_{\mathrm{i}}(\mathrm{RIM}, \mathrm{OC}, \mathrm{WC}), \mathrm{i}=1,2,3
$$


where RIM is the household's income relative to other households possessing similar characteristics. ${ }^{1}$

Our goal is to empirically estimate the relationship between each measure of job satisfaction and whether the occupation is gaming or non-gaming. Our alternate hypotheses are thus,

$$
\begin{aligned}
& \mathrm{S}_{1}(\bullet, \mathrm{GAME}=1)<\mathrm{S}_{1}(\bullet, \mathrm{GAME}=0), \\
& \mathrm{S}_{1}(?, \mathrm{GAME}=1)<\mathrm{S}_{2}(\bullet, \mathrm{GAME}=0),
\end{aligned}
$$

and

$$
\mathrm{S}_{3}(\bullet, \mathrm{GAME}=1)<\mathrm{S}_{3}(\bullet, \mathrm{GAME}=0),
$$

where GAME is a dummy variable which takes on the value 1 if the individual's occupation is in the gaming industry.

One estimation issue that arises is how to calculate a meaningful measure of relative household income from our data. Given detailed information on each household, an income equation could be estimated and the results used to calculate the expected income of a household with a given set of characteristics. The relative income would then be the difference between the household's expected income and its actual income. However, our income data is categorical and is not refined enough to allow the estimation of an income equation directly. To get around this problem, we estimate an ordered probit with the income category as the dependent variable. The results of this probit allow us to calculate the probability that the income of a particular household with a given set of characteristics will lie within a particular income category. Our measure of relative income is then computed as the probability that income will lie in a category higher than the household's actual income category. For example, given our eight income categories $\left(\mathrm{I}_{0}, \ldots, \mathrm{I}_{7}\right)$, an ordered probit allows us to calculate $\operatorname{Prob}\left(\mathrm{I}=\mathrm{I}_{\mathrm{i}}\right)$ for $\mathrm{i}=0, \ldots, 7$ for each worker. Given a household whose income lies in category k, the relative income measure would then be computed as $\mathrm{RIM}=\sum_{j>k} \operatorname{Prob}\left(\mathrm{I}=\mathrm{I}_{\mathrm{j}}\right)$. As income increases relative to its expected value (given age, education, among other characteristics), the value of RIM decreases. Those individuals with high values of RIM are expected to experience lower levels of satisfaction because of their lower relative income.

Another issue that must be addressed is the simultaneous determination of income and the nonpecuniary measures of job satisfaction as implied by Rosen's (1986) theory of compensating differences. To accommodate this simultaneity, two-stage least squares estimation is used (Greene 1997). The first stage yields predicted values for RIM, $S_{1}, S_{2}$, and $S_{3}$ which are then used as instruments in the second stage. In the second stage, the following functional relationships are estimated: ${ }^{2}$ 
(7) Satisfaction with "Working Conditions," $\mathrm{S}_{1}=$ $\alpha_{1}+\beta_{1}{ }^{1}$ GAME $+\beta_{2}{ }^{1}$ GENDER $+\beta_{3}{ }^{1}$ NONWHITE $+\beta_{4}{ }^{1}$ MIDDLE

$+\beta_{5}{ }^{1}$ YOUNG $+\beta_{6}{ }^{1}$ SHIFT $+\beta_{7}{ }^{1}$ PARTIME $+\beta_{8}{ }^{1}$ MGT

$+\beta_{9}{ }^{1}$ SERVWORK $+\beta_{10}{ }^{1}$ PROTECH $+\beta_{11}{ }^{1} \widehat{\text { RIM }}$,

(8) Satisfaction with "Job Quality," $\mathrm{S}_{2}=$

$\alpha_{2}+\beta_{1}{ }^{2}$ GAME $+\beta_{2}{ }^{2}$ GENDER $+\beta_{3}{ }^{2}$ NONWHITE $+\beta_{4}{ }^{2}$ MIDDLE +

$\beta_{5}{ }^{2}$ YOUNG $+\beta_{6}{ }^{2}$ SHIFT $+\beta_{7}^{2}$ PARTIME $+\beta_{8}^{2}$ MGT

$+\beta_{9}{ }^{2}$ SERVWORK $+\beta_{10}^{2}$ PROTECH $+\beta_{11}^{2}$ EDUC1

$+\beta_{12}{ }^{2}$ EDUC2 $+\beta_{13}{ }^{2}$ EDUC3 $+\beta_{14}{ }^{2}$ EDUC4

$+\beta_{15^{2}} \mathrm{DIFF}+\beta_{16^{2}} \widehat{\mathrm{RIM}}$,

(9) Satisfaction with "Compensation," $\mathrm{S}_{2}=$

$\alpha_{3}+\beta_{1}{ }^{3}$ GAME $+\beta_{2}{ }^{3}$ GENDER $+\beta_{3}{ }^{3}$ NONWHITE $+\beta_{4}{ }^{3}$ MIDDLE +

$\beta_{5}{ }^{3}$ YOUNG $+\beta_{6}{ }^{3}$ SHIFT $+\beta_{7}{ }^{3}$ PARTIME $+\beta_{8}{ }^{3}$ MGT

$+\beta_{9}{ }^{3}$ SERVWORK $+\beta_{10}{ }^{3}$ PROTECH $+\beta_{11}{ }^{3}$ OWNHOME

$+\beta_{12}{ }^{3}$ HHSIZE $+\beta_{13}{ }^{3}$ MARRIED $+\beta_{14}{ }^{3}$ DIVWIDSEP

$+\beta_{15}{ }^{3} \widehat{\text { RIM }}$,

and

(10) $\operatorname{Prob}\left(\mathrm{I}=\mathrm{I}_{\mathrm{i}}, \mathrm{I}=0 . .7\right)=\Phi\left(\alpha_{4}+\beta_{1}{ }^{4} \mathrm{GAME}+\beta_{2}{ }^{4} \mathrm{GENDER}+\beta_{3}{ }^{4} \mathrm{NONWHITE}\right.$

$+\beta_{4}{ }^{4}$ MIDDLE $+\beta_{5}{ }^{4}$ YOUNG $+\beta_{6}{ }^{4}$ SHIFT $+\beta_{7}{ }^{4}$ PARTIME

$+\beta_{8} 4 \mathrm{MGT}+\beta_{9}{ }^{4}$ SERVWORK $+\beta_{10} 4$ PROTECH $+\beta_{11} 4$ EDUC1

$+\beta_{12}{ }^{4}$ EDUC2 $+\beta_{13}{ }^{4}$ EDUC3 $+\beta_{14}^{4}$ EDUC4 $+\beta_{15}{ }^{4}$ ONEARN

$+\beta_{16}{ }^{4}$ HOWLONG $+\beta_{17} 4$ HOWLONG3 $+\beta_{18}{ }^{4}$ HOWLONG4

$+\beta_{19}{ }^{4}$ HOWLONG5 $+\beta_{20} 4 \widehat{S_{1}}+\beta_{21}{ }^{4} \widehat{S_{2}}+\beta_{22}{ }^{4}$ ),

where $\Phi(\bullet)$ is the standard normal distribution function.

Job satisfaction depends on individual characteristics, such as education, race (Bartel, 1981), and gender (Hodson 1989). To capture these effects, we include the dummy variables EDUC1 (=1 if, at most, the respondent has completed high school ), EDUC2 (=1 if, at most, the respondent has attended college), EDUC3 (=1 if, at most, the respondent has a college degree and/or has some graduate training), EDUC4 ( $=1$ if the respondent has a graduate degree), NONWHITE ( $=1$ if race is other than white), and GENDER ( $=1$ if female). Education level is expected to influence satisfaction with job quality; however, the effect is likely ambiguous. Education may be positively related to job satisfaction reflecting access to better, more satisfying jobs. On the other hand, it may also exert a negative effect if more educated workers have higher employment expectations and higher rates of under- 
employment (Borjas 1978, Lee and Mowday 1987, Idson 1990). Race and gender are expected to influence all measures of job satisfaction. Since discrimination may be intangible, black and female workers may be less satisfied with their jobs than identical white male workers (Laband and Lentz 1993). Other research, however, has demonstrated that black and female workers are more satisfied with their jobs than their white and male counterparts, partially explained by differing expectations concerning job rewards (Bartel 1981, Hodson 1989). These conflicting results suggest that race and gender are important variables to include in our model, but a priori predictions of their expected impact remain uncertain.

Mobility between jobs acts as a sorting process, which naturally results in mature workers being in jobs that correspond more closely to their expectations. Other things equal, job satisfaction is, therefore, expected to be positively related to age. To account for these effects we include the dummy variables MIDDLE (=1 if age is $35-54$ years) and YOUNG (=1 if age is 18-34 years).

Occupational characteristics will also likely impact job satisfaction. To capture these influences, we include the variables SHIFT ( $=1$ if the work takes place at evening or at night), PARTIME ( $=1$ if the occupation involves less than 35 hours per week), MGT ( $=1$ if the occupation is a management position), SERVWORK ( $=1$ if the occupation is service oriented, irrespective of industry), PROTECH (=1 if the occupation is in a professional/technical field). In addition, the variable DIFF (=1 if the respondent was trained or educated for an occupation different than the current one) is included as a likely determinant of satisfaction with job quality.

Satisfaction with compensation is also expected to depend on household characteristics such as OWNHOME ( $=1$ if the household owns rather than rents its home), HHSIZE (= the number of people in the household), MARRIED (= 1 if the respondent is married), and DIVWIDSEP ( $=1$ if the respondent is divorced, widowed, or separated). A household that is able to own its own home is more likely to be satisfied with compensation. Thus, the effect of OWNHOME is expected to be positive. The latter three variables reflect demands on the household's funds. The more demands that can be fulfilled, the more satisfied a household is expected to be with its compensation.

Household income falls into one of eight possible categories: $\$ 0-\$ 14,999$, $\$ 15,000-\$ 19,999, \$ 20,000-\$ 24,999, \$ 25,000-\$ 34,999, \$ 35,000-\$ 49,999, \$ 50,000 \$ 74,999$, $\$ 75,000-\$ 99,999$, and over $\$ 100,000$. The probability that a particular household falls into one of these income categories depends upon gender, race, age, and human capital variables, as well as the household's occupational characteristics. In addition, household income will depend upon the number of income earners in the household and the permanence of the household in the local economy. The longer the household has been located in the area, the higher its income is expected to be. To account for these effects we use the variables ONEARN ( $=1$ if the household is a single income household), HOWLONG2, HOWLONG3, HOWLONG4, and HOWLONG5 which equal 1 if the household has been located in Southern Nevada for 1 to 5 years, 6 to 10 years, 11 to 20 years, or more than 20 years, respectively. 


\section{ESTIMATION RESULTS}

The regression results on the job satisfaction measures for the second stage are given in Table 4 .

TABLE 4

Two-Stage Least Squares Estimates of Job Satisfaction Equations (t statistics in parentheses)

\begin{tabular}{cccc}
\hline Independent Variables & \multicolumn{3}{c}{ Equation } \\
\cline { 2 - 4 } & $\begin{array}{c}\text { Satisfaction with } \\
\text { Conditions, } \mathrm{S}_{1}\end{array}$ & $\begin{array}{c}\text { Satisfaction with } \\
\text { Job Quality, } \mathrm{S}_{2}\end{array}$ & $\begin{array}{c}\text { Satisfaction with } \\
\text { Compensation, } \mathrm{S}_{3}\end{array}$ \\
\hline CONSTANT & $-0.082(-0.29)$ & $0.65(1.76)$ & $-0.062(-0.18)$ \\
GAME & $-0.86(-4.90)$ & $-.030(-1.74)$ & $0.077(0.44)$ \\
GENDER & $0.057(0.50)$ & $-0.091(-0.82)$ & $0.027(0.24)$ \\
NONWHITE & $-0.11(-0.53)$ & $-0.12(-0.60)$ & $-0.13(-0.67)$ \\
MIDDLE & $0.044(0.25)$ & $-0.42(-2.41)$ & $-0.13(-0.72)$ \\
YOUNG & $0.089(0.49)$ & $-0.45(-2.50)$ & $0.079(0.41)$ \\
SHIFT & $-0.055(-0.34)$ & $0.12(0.74)$ & $0.23(1.42)$ \\
PARTIME & $-0.034(-.013)$ & $0.047(0.19)$ & $-0.73(-2.82)$ \\
MGT & $0.53(2.16)$ & $0.11(0.46)$ & $-0.37(-1.51)$ \\
SERVWORK & $0.21(0.92)$ & $-0.14(-0.61)$ & $-0.26(-1.59)$ \\
PROTECH & $-0.084(-0.38)$ & $0.18(0.84)$ & $-0.35(-1.59)$ \\
RIM & $0.16(0.58)$ & $-0.78(-2.74)$ & $-0.74(-2.36)$ \\
EDUC1 & n.a. ${ }^{1}$ & $-0.11(-0.42)$ & n.a. \\
EDUC2 & n.a. & $-0.28(-1.15)$ & n.a. \\
EDUC3 & n.a. & $-0.12(-0.45)$ & n.a. \\
EDUC4 & n.a. & $0.10(0.37)$ & n.a. \\
DIFF & n.a. & $-0.32(-2.54)$ & n.a. \\
OWNHOME & n.a. & n.a. & $0.24(1.73)$ \\
HHSIZE & n.a. & n.a. & $0.047(1.01)$ \\
MARRIED & n.a. & n.a. & $-0.047(-0.27)$ \\
DIVWIDSEP & n.a. & n.a. & $0.36(1.87)$ \\
\hline F & 0.106 & 0.179 & $0-.088$ \\
observations & 3.38 & 4.20 & 326 \\
\hline
\end{tabular}

${ }^{1}$ This variable is not included in this regression equation.

The coefficient estimates on the "Gaming Occupation" variable are quite large, negative, and statistically significant in the "Working Conditions" and "Job Quality" equations. These results reinforce the chi square findings that employees in the gaming industry are significantly less satisfied with the nonpecuniary aspects of their jobs than those employed in other industries. The same cannot be said, however, for satisfaction with the pecuniary dimension. The sign of the parameter is positive, as expected, although not significantly different from zero, suggesting there is no difference in the pecuniary dimension.

To insure that we are not capturing other occupational characteristics such as shift work or part-time work in our measure of gaming occupations, we control for 
these two variables. The only statistically significant result is the coefficient on the part-time variable in the pecuniary factor equation. Not surprisingly, part-timers are less likely than their full-time counterparts to be satisfied with factors such as pay, benefits, and security. In addition, we control for broad occupational categories such as management, service work, and professional and technical work. These results reveal that respondents describing themselves as managers have a significantly higher degree of job satisfaction along the dimension of "Working Conditions." The other parameter estimates on these occupational variables are not statistically significant at conventional levels, suggesting that there is no perceptible difference in satisfaction with "Job Quality" and "Compensation." Relative to older workers, middle-aged and young workers are less satisfied with the quality of their jobs. This may indicate that older workers are more mobile professionally and are able to self-select into occupations which they view more meaningful.

The analysis also suggests that, everything else equal, households with higher relative income (a lower RIM number) are more satisfied with the "Job Quality" and "Compensation" components of job satisfaction. Relative income does not appear to affect satisfaction with "Working Conditions," however.

The marginal effects for the ordered probit on the satisfaction measures are presented in Table 5. These findings suggest that compensating differentials are paid along the "Job Quality" dimension $\left(\mathrm{S}_{2}\right)$. Observe that as the "Job Quality" measure increases, the likelihood a respondent will be located in a higher income category decreases, which is the expected result. The parameter estimates on the other two satisfaction variables are not statistically significant, indicating that compensating differentials are not evident.

TABLE 5

Ordered Probit Results for Job Satisfaction Measures (standard errors in parentheses)

\begin{tabular}{cccccccccc}
\hline & & \multicolumn{7}{c}{ Marginal Effects on the Probability of Lying Within Income Category } \\
\cline { 3 - 10 } $\begin{array}{c}\text { Independent } \\
\text { Variable }\end{array}$ & Coefficient & $\$ 14,999$ & $\$ 15,000-$ & $\$ 20,000-$ & $\$ 25,000-$ & $\$ 35,000-$ & $\$ 50,000-$ & $\$ 75,000-$ & $\$ 100,000$ \\
$\widehat{\mathrm{S}_{1}}$ & $1.25(0.88)$ & 0.023 & 0.068 & 0.13 & 0.19 & 0.064 & -0.24 & -0.15 & -0.088 \\
$\widehat{\widehat{\mathrm{S}_{2}}}$ & $1.36(0.30)$ & 0.025 & 0.074 & 0.14 & 0.21 & 0.070 & -0.26 & -0.16 & -0.096 \\
$\widehat{\widehat{\mathrm{S}_{3}}}$ & $0.60(0.56)$ & 0.011 & 0.033 & 0.064 & 0.091 & 0.031 & -0.12 & -0.071 & -0.042 \\
\hline
\end{tabular}

'Chi-square statistic for the ordered probit is $\mathbf{1 7 9 . 4 2}$.

*Variable is statistically significant at the $10 \%$ level.

\section{CONCLUSIONS}

The results of this analysis indicate that, after controlling for a number of occupational and individual characteristics, occupations in the gaming industry appear to be ranked lower in two of the three job satisfaction dimensions than occupations in other industries. This result suggests that lower levels of nonpecuniary rewards ("Working Conditions" and "Job Quality") accrue to gaming industry workers relative to those in similar jobs in other industries. In terms of "satisfaction 
with pecuniary benefits," we found no significant differences between gaming and nongaming occupations.

Our analysis of the marginal effects of job satisfaction on income using ordered probit analysis reveals evidence of compensating differentials along the "Job Quality" dimension. We found no evidence of compensating differentials for "Working Conditions." Unfortunately, the categorical income data is too imprecise to make reliable estimates of the size of the compensating differential. Such an estimate would be useful for decision makers in comparing development alternatives.

If community decision makers are considering the option of gaming to develop their local and regional economies, it is important that they are aware of both pecuniary income and nonpecuniary income generated from the employment created. Of course, economic developers might suggest that job quality for the unemployed is lower than almost all other options. As such, the creation of jobs, even if of marginal quality, is probably beneficial. Nonetheless, developers may overstate the benefits of jobs created if nonpecuniary quality parameters are below those of alternative development options.

Our research also provides insight into the dimensions of gaming occupations that workers tend to be least satisfied with. Among these dimensions are "recognition for a good job," "independence in work," "meaningfulness of work," "interest in the job," and "interactions with people on the job." Our findings may be useful to gaming management officials. Steps to increase job satisfaction will likely reduce turnover costs and increase productivity.

Additional research in three areas would provide more confidence in the inferences drawn from this study and facilitate the implementation of these ideas in future economic impact assessments of gaming projects. First, more in-depth study of the nature of job satisfaction among gaming employees would be useful. For example, qualitative research methodology making use of observation and interviews of all types of gaming employees would likely reveal additional insight into specific human resource practices and job characteristics that may contribute to low job satisfaction levels. It is important to determine whether low job satisfaction is inherent in the work or whether it stems from alterable human resource practices that may differ across organizations.

Second, findings based on Las Vegas, though universally recognized as a center of gaming activity, may not always be directly transferable to other locations. In particular, one might expect transitory effects in areas for which legalized casino gambling is relatively new. Nevertheless, data gathered from gaming industry workers in other locations would further generalize our results.

Third, three potentially important variables need to be observed in future research. In particular, new data ought to include information on respondents' union status, size of workplace, and individual earnings. Previous research has demonstrated a negative relationship between union membership and job satisfaction in nationally representative data sets (Borjas 1978). If gaming industry workers are more highly unionized, this may bias the results against gaming occupations. There is evidence, however, that the union effect may be organizationally 
specific. In a more recent study of the union effect on satisfaction, Gordon and Denisi (1995) find that among public sector employees and university faculty, union membership does not affect job satisfaction. Pfeffer and Davis-Blake (1990) find that after adjusting for a number of occupational attributes, unionization actually contributed to increased job satisfaction. Additional research controlling for union status would likely increase the precision of our estimates and confidence in our results.

Similarly, if firm size is negatively related to job satisfaction and gaming occupations are concentrated in large firms with their tendency toward more formal, regimented, rule-oriented structures of work, then perhaps the gaming occupation variable is picking up variation due to large firm size. Idson (1990) and Lang and Johnson (1994) examine firm size as it relates to job satisfaction. Both studies find evidence that firm size is negatively correlated with job satisfaction.

Additional information on individual income would also be useful. New data should include more details, such as wage rate, hours of work, proportion and amounts of income generated from tips, and respondents' assessment of the nonpecuniary value of their jobs. New data of this sort would provide for more precise estimates of the impact of earnings on satisfaction and facilitate the calculation of quantitative estimates of nonpecuniary aspects of jobs in the gaming and nongaming sectors. Quantitative estimates of nonpecuniary returns could then be included in impact analyses to assist decision makers in determining the feasibility of gaming as a development option.

\section{REFERENCES}

Akerlof, George A., Andrew K. Rose, and Janet L. Yellen. "Job Switching and Job Satisfaction in the U.S. Labor Market." Brookings Papers on Economic Activity 2 (1988): 495-594.

Alm, James, Michael Mckee, and Mark Skidmore. "Fiscal Pressures, Tax Competition, and the Introduction of State Lotteries." National Tax Journal 46 (1993): 463-76.

Bartel, Ann P. "Race Differences in Job Satisfaction: A Reappraisal." Journal of Human Resources 16 (1981): 294-303.

Borjas, George J. "Job Satisfaction, Wages, and Unions." Journal of Human Resources 14 (1978): 21-40.

Center for Business and Economic Research. Las Vegas Perspective. Las Vegas, NV: University of Nevada, Las Vegas, 1992.

Darcy, Paula and David Lester. "Job Satisfaction in Casino Dealers." Psychological Reports 77 (1995): 642.

Freeman, R. B. "Job Satisfaction as an Economic Variable." American Economic Review 68 (1978): 135-41.

Frey, James H. "Labor Issues in the Gaming Industry." In William R. Eadington and John Rosencrance (eds.) Nevada Public Affairs Review. Reno, NV: Senator Alan Bible Center for Applied Research (1986): 32-38. 
Goodman, Robert. Legalized Gambling as a Development Strategy. Northampton, MA: United States Gambling Study (1994).

Gordon, Michael E., and Angelo S. Denisi. "A Reexamination of the Relationship between Union Membership and Job Satisfaction." Industrial and Labor Relations Review. 48 (1995): 222-36.

Greene, William H. Econometric Analysis. 3rd Edition. Englewood Cliffs, NJ: Prentice Hall, 1997.

Hammermesh, David S. "Economic Aspects of Job Satisfaction." In Orley C. Ashenfelter and Wallace C. Oates (eds.) Essays in Labor Market and Population Analysis. New York: John Wiley and Sons, 1977.

Hodson, R. "Gender Differences in Job Satisfaction: Why Aren't Women More Dissatisfied." The Sociological Quarterly 30 (1989): 385-99.

Idson, T. L. "Establishment Size, Job Satisfaction and the Structure of Work." Applied Economics 22 (1990): 1007-1018.

Killingsworth, Mark R. Labor Supply. Cambridge, MA: Cambridge University Press, 1983.

Kline, Paul. An Easy Guide to Factor Analysis. London: Routledge, 1994.

Laband, David N., and Bernard F. Lentz. "Is There Sex Discrimination in the Legal Profession? Further Evidence on the Tangible and Intangible Margins." Journal of Human Resources 28 (1993): 230-258.

Lang, James R., and Nancy B. Johnson. "Job Satisfaction and Firm Size: An Interactionist Perspective." The Journal of Socio-Economics 23 (1994): 405-23.

Lee, T.W,. and R.T. Mowday. "Voluntarily Leaving an Organization: An Empirical Investigation of Steers and Mowday's Model of Turnover." Academy of Management Journal 30 (1987): 721-743.

McCue, K., and W. R. Reed. "New Evidence on Workers' Willingness to Pay for Job Attributes." Southern Economic Journal 62 (1996): 627-52.

Pfeffer, Jeffrey, and Allison Davis-Blake. "Unions and Job Satisfaction: An Alternative View." Work and Occupations 17 (1990): 259-83.

Robinson, Edward A. "America's Most Desired Companies." Fortune (March 3, 1997): 68-70.

Rosen, Sherwin. "The Theory of Equalizing Differences." In Ashenfelter, O. and R. Layard (eds.) Handbook of Labor Economics 1 (1986).

Smith, Ronald W., Fredrick Preston, and Harry L. Humphries. "Alienation from Work: A Study of Casino Card Dealers." In William Eadington (ed.) Gambling and Society: Interdisciplinary Studies. Springfield, IL: Charles Thomas Publishers, 1975: 229-246.

Thurow, Lester C. "Psychic Income: Useful or Useless?" American Economic Review 68 (1978): 142-45. 